\title{
Using inverse analysis to estimate hydraulic properties for unsaturated layered sand
}

\author{
To Viet Nam ${ }^{*}$, Nguyen Viet Ky
}

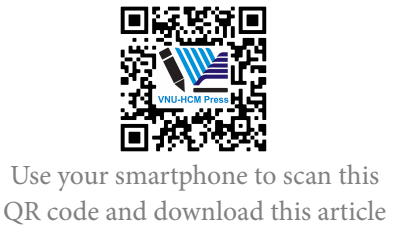

\begin{abstract}
In order to better evaluate the applicability of the inverse analysis method for calculation and evaluation of hydraulic properties of unsaturated soil in more realistic conditions, a transient one - step outflow experiment for layered sands was applied in the desaturation process with the purpose to attain the profiles of suction, saturation and flow rate with time. In this study, the fine sand and medium sand were used with the same thickness of $40 \mathrm{~cm}$ for each layer. The sand grains were mixed under water and scooped into the plexiglas column $(H=80 \mathrm{~cm}, \mathrm{D}=28 \mathrm{~cm}$, wall thickness $=$ $1 \mathrm{~cm})$ to prepare a fully saturated sample. For homogeneity within each sand layer, the density of two sands must be controlled during soil column construction. For numerical study, the inverse simulation and one straightforward calculation were carried out to determine the unsaturated hydraulic properties of sands. Unsaturated hydraulic parameters in the van Genuchten model were estimated using soil suction measurements at $10 \mathrm{~cm}$ intervals and an outflow rate at the bottom of a layered sand column. To reduce the quantity of data for analysis and simulation but still keep enough typical information for the experiment, four data sets of soil suction and saturation at four locations ( $L 2, L 4, L 5$ and $L 8)$ were selected out of eight to compile the Soil Water Characteristic Curve (SWCC). The comparison between predicted unsaturated hydraulic properties and the experimental unsaturated hydraulic properties shows good agreement in the case of the fine sand was overlaid with medium sand. The results concluded that besides the homogeneous sand, the inverse analysis based on the 1-D outflow experiment promises to be a useful method in determining the hydraulic properties for unsaturated heterogeneous sand.
\end{abstract}

Key words: unsaturated permeability, inverse problem, one-dimension column test, finiteelement method, soil heterogeneity
Dept of Geotechnics, Ho Chi Minh University of Technology

\section{Correspondence}

To Viet Nam, Dept of Geotechnics, Ho Chi Minh University of Technology

Email: tovietnam@hcmut.edu.vn

History

- Received: 25-3-2020

- Accepted: 04-11-2020

- Published: 13-11-2020

DOI : 10.32508/stdjsee.v4i2.527

\section{Check for updates}

\section{Copyright}

(c) VNU-HCM Press. This is an openaccess article distributed under the terms of the Creative Commons Attribution 4.0 International license.

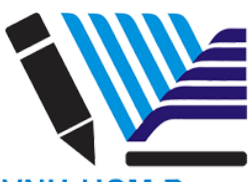

VNU-HCM Press

\section{INTRODUCTION}

The unsaturated hydraulic properties of soils are very important in providing the essential knowledge for solving many engineering problems in the geoengineering such as seepage, slope stability, bearing capacity, consolidation and settlement, water contamination, etc. The most traditional determinations of unsaturated soil hydraulic properties require relatively restrictive initial conditions and boundary conditions, and thus can be time-consuming, laborious, expensive and uncertainty for most practical applications ${ }^{1}$. To simplify and reduce the calculations of unsaturated hydraulic functions for soils, in general cases, the soils can be assumed as homogeneous soils. However, almost field soils are inherently heterogeneous, and idealized conditions of homogeneity are rarely encountered in nature (not to say that homogeneity in all aspects never occurs, in reality), even soils carefully prepared in a laboratory are not perfect homogeneity. Therefore, the values of hydraulic properties of unsaturated heterogeneous soils in many cases are more appropriate for solving many engineering problems. Accordingly, finding out a good method to determine accurately the hydraulic properties of unsaturated layered soils with the real conditions are not easy but necessary.

The determination of hydraulic conductivity for unsaturated homogeneous soils is an inherently complicated problem, so the determination of hydraulic conductivity for unsaturated heterogeneous soils is obviously more and more complex problem. Nowadays, two common approaches are usually used to determine and describe the unsaturated hydraulic properties in heterogeneous soils ${ }^{2,3}$.

The first approach assumes the heterogeneous system is replaced by an equivalent (effective) homogeneous media. In this case, the unsaturated hydraulic properties for equivalent homogeneous soil can be calculated by using the indirect methods developed for homogeneous media such as pedotransfer functions ${ }^{4}$, used texture for calculating hydraulic properties; Scaling techniques ${ }^{5}$, given the reasonable 
scale for formulated model to describe the movement of water in unsaturated soils; Multimodal water retention curves ${ }^{6}$, developed a modified water retention model to describe the water retention curve (WRC) of soils with multimodal pore systems; Inverse analysis $^{7-10}$, used numerical method with input data from experiment to estimate the unsaturated hydraulic properties; and Averaging method ${ }^{11}$, proposed the averaging schemes for computing hydraulic conductivity between two adjacent nodes of the computational grid. Due to soil heterogeneity, the hydraulic properties do not remain uniform and models based on this assumption give poor results ${ }^{12}$.

The second approach estimates the hydraulic properties of the specific layer in unsaturated heterogeneous soils to establish a detailed deterministic model. In this way, the soil within layers is assumed homogeneous soil. In other words, although there are the variances of suction, saturation, void ratio, etc., in a layer, the heterogeneity within layers is ignored. There are some researches had been used to determine the unsaturated hydraulic properties following the second approach, such as: Laboratory study ${ }^{13}$, analyzed unsaturated flow of water moving steadily through an isothermal two-layer soil using Darcy's equation Fixed Gradient Models ${ }^{14}$, used to model drainage from unsaturated layered soils Numerical analysis ${ }^{15}$, developed an useful algorithm to estimate the interlayer hydraulic conductivity for unsaturated layered soils; Multiphase flow experiments and image analysis technique ${ }^{16}$, conducted to investigate the effect of textural interfaces on water pressure and nonaqueous phase liquid pressure and estimate the saturation distribution during infiltration and drainage. This approach was applied to nearer real conditions than the first approach. However, to find a faster, more accurate and more realistic calculation method is always the aim of the researchers.

In this study, the second approach was applied combined with inverse analysis. In order to apply this approach, the hydraulic parameters for the specific soil layer must be determined. In a layered medium, the number of parameters increases proportionally with the number of layers and require too much data and computational effort ${ }^{17}$. Recently, ecause of major advances in computational techniques and computer power, the possible technique for obtaining these effective values is to conduct an inverse method, e.g., by minimizing the differences between the values predicted by the homogeneous equation and observed values. The successful application of the inverse modeling technique for determining the unsaturated soil properties improves both speed and accuracy, and promise to be the dominated technique for solving the problems in geotechnical engineering particularly, engineering and physical sciences generally. The previous research had focused on the applicability of the inverse analysis method for determination of unsaturated soil hydraulic properties of flow through homogeneous porous media using one-dimension outflow experiment ${ }^{18}$. For the further research, the objectives of this study are: to evaluate the applicability of an inverse analysis for estimating the hydraulic properties for unsaturated layered sands from 1-D outflow experiment; to consider the performance of independent forward simulation using existing hydraulic parameters of two types of sand obtained from the previous experiments for a single layer system.

\section{MATERIALS AND METHODS}

\section{Materials}

In this study, the laboratory experiment of vertical drain for layered sand column, which consisted of two sands, was described. Two sands used for the experiments in this chapter were medium sand and fine sand. The properties of two sands are shown in Table 1.

The properties shown in Table 1 reveal that two sands are classified as poor grade sand $\left(\mathrm{C}_{u}<6\right.$ and $\mathrm{C}_{c}<1$ or $\mathrm{C}_{c}>3$; ASTM D-2487). In other words, the sands used in the present study are very uniform.

The SWCC references of two sands obtained from independent experiments for column sand in 1-D outflow condition, one from the previous study for medium sand ${ }^{18}$, another from the similar experiment for fine sand, are shown in Figure 1. In which, the hydraulic parameters of medium sand and fine sand are $P_{0 m}=1.29$ and $\lambda_{m}=0.882 ; P_{0 f}=3.32$ and $\lambda_{f}=0.889$, respectively.

\section{Experimental method}

The same Plexiglas column in previous research was also used to conduct drainage test and was attached with eight tensiometers and eight electrical resistivity probes (ERP) along the sample (Figure 2 a and Figure $2 \mathrm{~b}$ ). The base of column overlaid on fine mesh with the mesh size number of 200 . This mesh rested on an acrylic plate with honeycomb shape of $8 \mathrm{~mm}$ circular holes. A tipping bucket funnel was placed right beneath the acrylic plate and connected to the burette, which can change the water table in the soil column by change the free outflow level of water in the burette ${ }^{18,19}$.

To easily pack and unpack soil column, the Plexiglas column was separated into individual sections. These sections can be connected to each other using 
Table 1: The properties of medium sand and fine sand

\begin{tabular}{|c|c|c|c|c|c|c|}
\hline Sample & $\begin{array}{l}\text { Specific grav- } \\
\text { ity } \\
\left(\mathrm{G}_{S}\right)\end{array}$ & $\begin{array}{l}\text { Coefficient of } \\
\text { uniformity } \\
\left(\mathrm{C}_{u}\right)\end{array}$ & $\begin{array}{l}\text { Coefficient of } \\
\text { gradation } \\
\left(\mathrm{C}_{c}\right)\end{array}$ & $\begin{array}{l}\text { Median grain } \\
\text { size } \\
\text { D50 }(\mathrm{mm})\end{array}$ & $\begin{array}{l}\text { Maximum } \\
\text { void ratios } \\
\left(\mathrm{e}_{\max }\right)\end{array}$ & $\begin{array}{l}\text { Minimum void } \\
\text { ratios } \\
\left(\mathrm{e}_{\min }\right)\end{array}$ \\
\hline $\begin{array}{l}\text { Medium } \\
\text { sand }\end{array}$ & 2.66 & 1.65 & 0.94 & 0.55 & 0.99 & 0.60 \\
\hline Fine sand & 2.7 & 1.73 & 0.98 & 0.18 & 1.22 & 0.73 \\
\hline
\end{tabular}

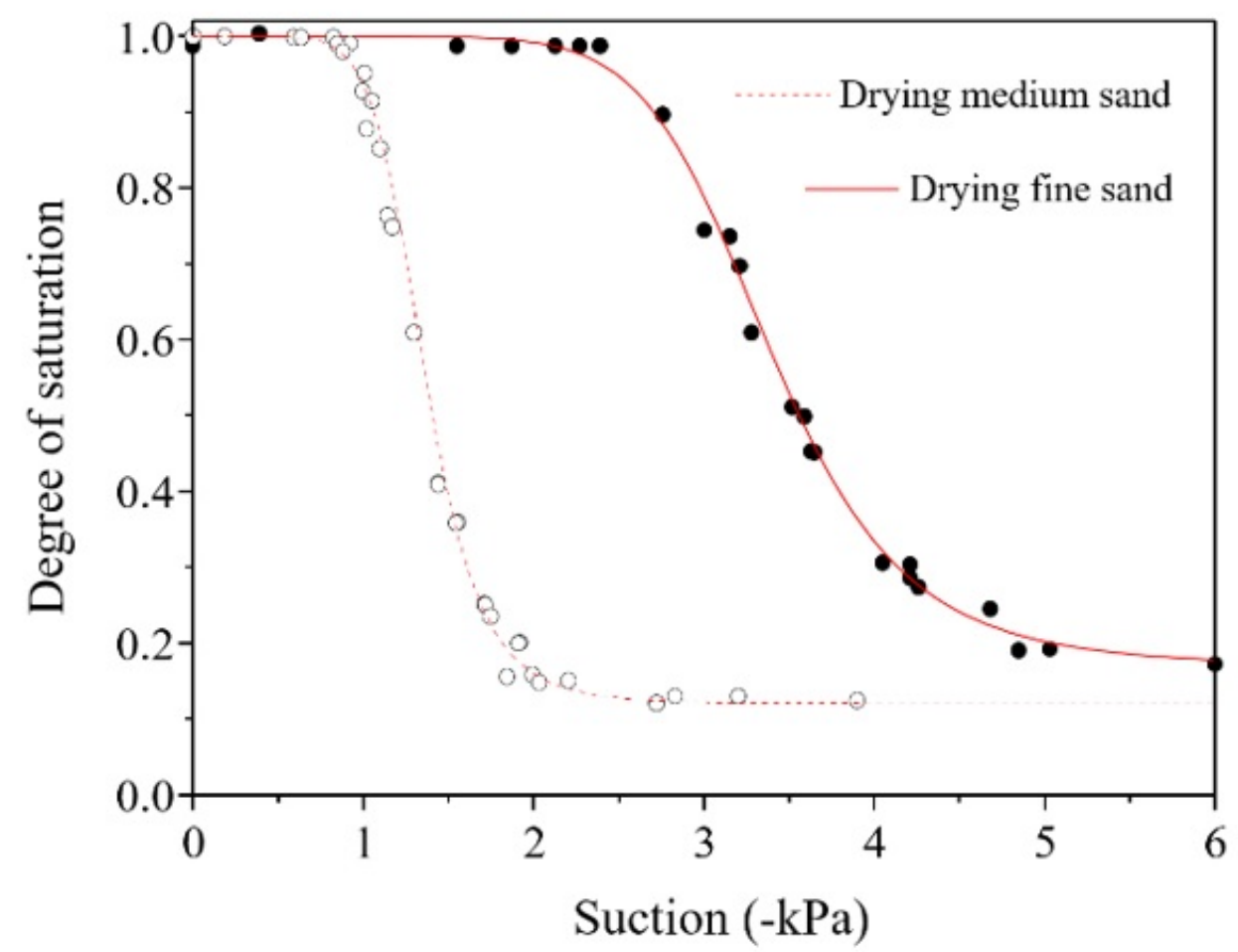

Figure 1: The drying SWCC of medium sand and fine sand determined from independent experiments.

screws with an O-ring seal placed within a groove in the base of every section to prevent water from leaking out between sections. Eight sampling ports having the same elevation and diameter with tensiometer and ERP ports were made along the height of the soil column. At the end of the experiment, the small samples of sands can be extracted through these sampling ports easily and used for gravimetric water content analysis to make sure that the water content (degree of saturation) values get from ERPs is reliable.

The degree of saturation of soil at different locations in soil column and different times during draining test was calculated by using calibration curves, which were built with exponents were fitted using Archie's law (Equation 1) ${ }^{20}$. As the results of independent experiments, the fitting exponents of calibration curves for medium sand and fine sand are $m_{m}=1.32, n_{a m}$ $=1.57$ and $m_{f}=1.68, n_{a f}=1.93$, respectively (Figure 3).

$$
S_{w}=\left(\frac{\rho_{w} n^{-m}}{\rho}\right)^{\frac{1}{n_{a}}}
$$

where $S_{w}$ is degree of saturation, $m$ and $n_{a}$ are the Archie exponent, $n$ is the porosity of soil, $\rho$ is soil resistivity, and $\rho_{w}$ is resistivity of water.

The sand grains were slurry packed (filling the column with water and then slowly pouring or sprinkling dry sand into the column) into the column to prepare a fully saturated sample ${ }^{21}$. The density of two sands must be controlled during soil column construction. The temperature in the laboratory was 
(A)

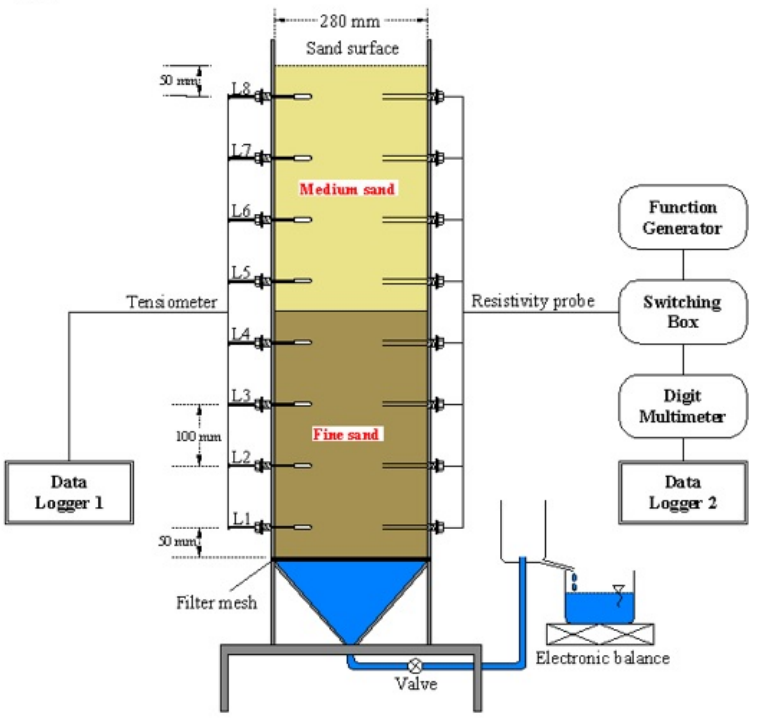

(B)

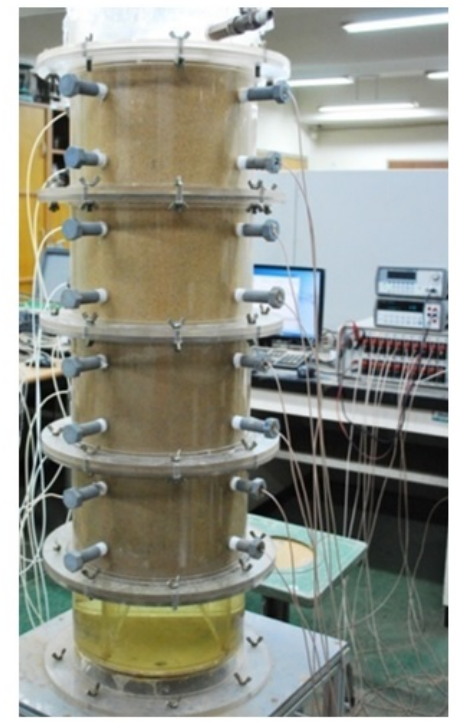

Figure 2: (A) The schematic diagram of column test; (B) The laboratory test for layered system

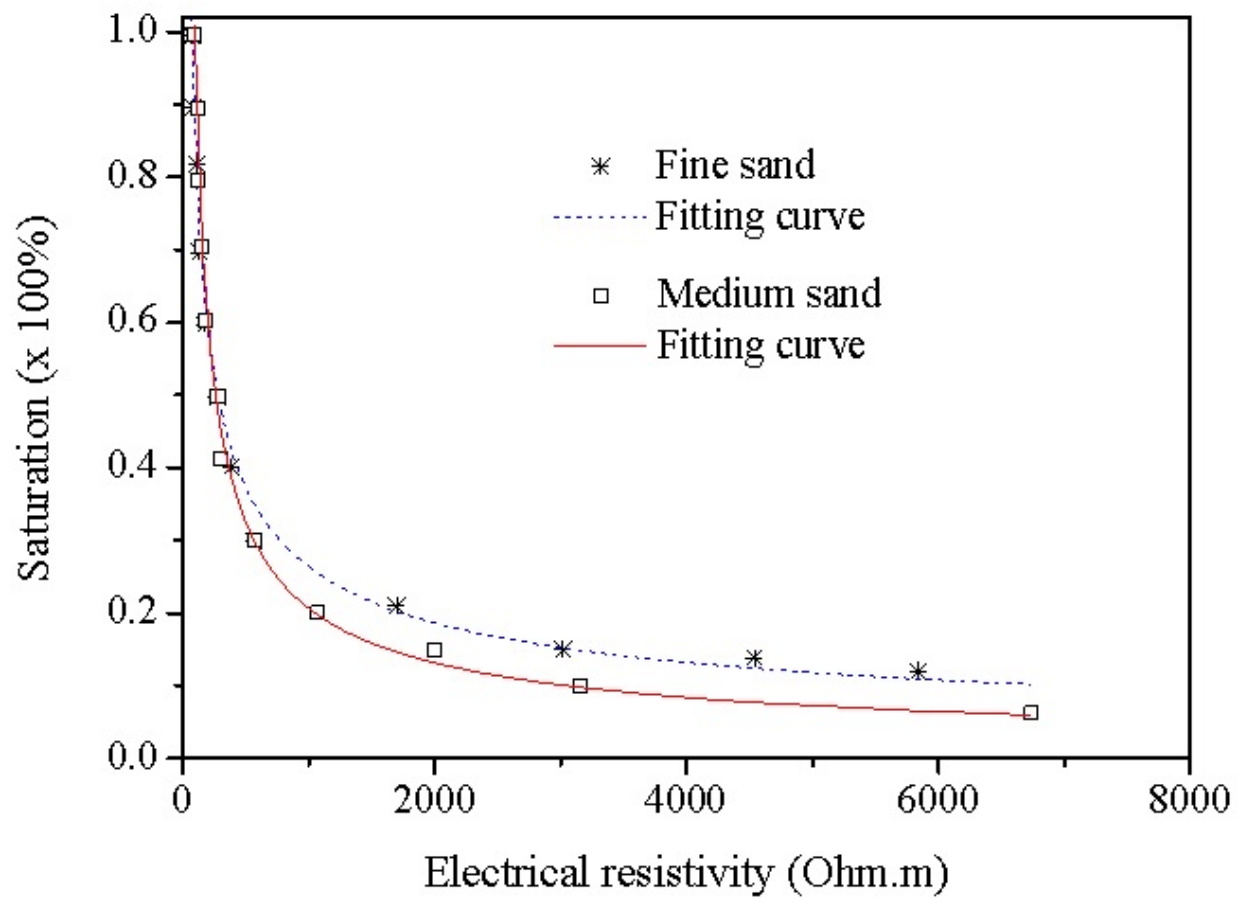

Figure 3: Calibration relationship between electrical resistivity and saturation for: solid-line for medium sand; dash-line for fine sand. 
maintained at $20^{\circ} \mathrm{C}$ to prevent a change in water-air surface tension $^{22}$.

In the study, only one-step outflow experiment was conducted for the experiment. Therefore, in the experiment, outflow was maintained at the bottom level of the column during the test. Time intervals for measuring the soil suction, soil resistivity and cumulative outflow were around 10s, which make sure that the quick change of soil suction, soil resistivity and outflow rate can be recorded with an equal temporal resolution ${ }^{1}$.

\section{Numerical method}

The inverse analysis consists of the identification of parameters in models for these coefficients. The inverse calculation was carried out using two computer models, one for forward flow modeling and the other for nonlinear optimization.

\section{Forward modeling}

The one-dimension water balance equation, wellknown Richards' equation, was used to describe the 1-D water flow in the soil sample:

$$
\frac{\partial}{\partial t}\left[\rho_{l}^{w} \phi S_{l}\right]+\underset{\sim}{\nabla} \cdot\left[\underset{\sim}{\rho_{l}^{w}} \underset{\sim}{q}\right]=0
$$

where $\underset{\sim l}{q}=-k\left(\frac{\partial h}{\partial z}-1\right), \phi$ is the porosity of the soil, $S_{l}$ is saturation of liquid water, $\rho_{l}^{w}$ is mass of water per unit volume in the liquid phases, $\underset{\sim}{q}$ is the liquid flow flux in liquid phase, $\mathrm{k}$ is the hydraulic conductivity, $h$ is the pressure head, and $z$ is the depth which is positive upward from the sample bottom.

The soil water retention curve and unsaturated hydraulic conductivity function can be described by various expressions. However, with the good results in determination of unsaturated hydraulic properties for the homogeneous sand column were shown in the previous study, for convenience, the parametric form of van Genuchten model (1980) is applied again to describe the SWCC and unsaturated relative hydraulic conductivity for layered sands in this chapter ${ }^{18,23}$.

\section{Nonlinear optimization}

A non-linear optimization method used to minimize the objective function was $\mathrm{L}_{2}$ error norm, which expresses the difference between observed and predicted data by using the least-square solution for the parameters in van Genuchten's equation ${ }^{18,24}$. In the inverse analysis, when many measurements are available, the system of equation can be expressed:

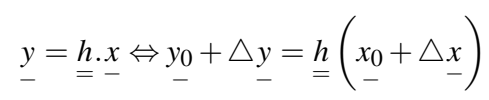

where $\underline{x}$ are unknown soil properties, $\underline{h}$ is the transformation matrix which is $h_{i j}=\partial y_{i} / \partial x_{j}$..

The error for the measurements is established between measured value $y^{<m>}$ (saturation, pressure head, outflow, displacements, stresses, etc.) and predicted value $y$

$$
\begin{aligned}
e & =\underset{=}{W}\left(y^{<m>}-\frac{y}{-}\right) \\
& =\underset{=}{W}\left[y^{<m>}-\left(\begin{array}{l}
y_{0}+\Delta y \\
-
\end{array}\right)\right]
\end{aligned}
$$

Therefore, the objective function $(\Gamma)$ to be minimized becomes:

$$
\begin{aligned}
& \Gamma=e^{T} \cdot e
\end{aligned}
$$

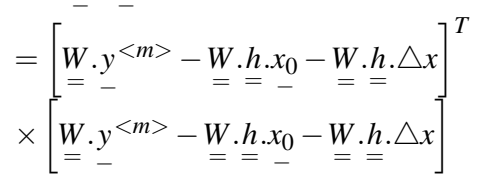

where $x_{0}$ is the initial guess of unknown variables, $y^{<m>}$ is the measurement data and $\underline{W}$ is the weight factor (where $\mathrm{W}_{i j}=$ weight value, $\mathrm{W}_{i j}=0$ for $\mathrm{i} \not \equiv \mathrm{j}$ ). In the optimization process, the minimization approach for the objective function and the sensitivity analysis are embedded into a multilevel algorithm. Minimization starts with the initial guess following van Genuchten parameters $P_{0}$ and $\lambda$. The values of initial guess parameters are repeatedly updated until a certain stopping criterion is satisfied, or the convergence criterion is achieved. At each step, the initial parameter values for the minimization are set by the result of the previous step to the new parameterization.

\section{RESULTS}

To reduce the quantity of data for analysis and simulation but still keep enough typical information for the experiment, the data at four locations of L2, L4, L5 and L8 was selected out of eight locations to perform, compile the SWCC and use as input data for simulation.

\section{Experimental results}

Similar to any previous one-step outflow experiments for grain soils under gravitational forces, the cumulative outflow and discharge rate also show rapid change during the short time after the beginning of testing because of the highest hydraulic gradient at initial testing. The cumulative outflow with time shows the steep slope during $50 \mathrm{~min}$ right after starting the test, and stopped flowing after $17 \mathrm{~h}$ with total outflow $Q \approx 15.4$ 
$\mathrm{cm}$ (Figure $4 \mathrm{a}$ ). The discharge rate reaches the highest value of $0.023 \mathrm{~cm} / \mathrm{s}$ at some seconds after beginning of the experiment. The discharge rate decreases corresponding to hydraulic pressure and was nearly constant after $250 \mathrm{~min}$ (Figure $4 \mathrm{~b}$ ).

In the independent experiments for fine and medium sands, the deformations of sands resulting from a change in loading or consolidation occurred immediately and were relatively small. Therefore, in this study, the void ratio of sands can be considered constant when evaluating unsaturated hydraulic properties ${ }^{18,25}$.

Immediately, after opening the bottom valve to allow free drainage, the lower end of the fine sand column was exposed to atmospheric pressure, and soil is allowed to drain by gravity at that moment, hence the pore water pressure started to drop at every location in the sand column (Figure 5 a). As shown in Figure 5 $b$, the distribution of pore water pressure for experiment was not hydrostatic at end of experiment $(t=3.0$ d).

Water drainage of the saturated models was initiated at time $t=0$. Figure 6 shows the vertical water saturation profiles measured by the ERP and calibration curve (Figure. 3). The saturation time series inferred from the four ERPs are shown in Figure. 6a. At the beginning of testing, the moisture content in the column was uniformly equal to $99 \%$. The soil saturation at different locations started to decrease only after the pore water pressure at those locations reached to neighboring value of air-entry values or when the capillary fringe passes through the profile.

The data shown in Figure 5 a and Figure 6 a may be further interpreted using isochrones of pore water pressure and degree of saturation with height in the sand column, shown in Figure $5 \mathrm{~b}$ and Figure $6 \mathrm{~b}$. The data in Figure $5 \mathrm{~b}$ and $6 \mathrm{~b}$ show how the pore water pressure and degree of saturation gradually change vertically downward through the profile. Since bottom layer is fine sand, the capillary fringe laid higher than locations of L1, L2 and L3. Therefore, the sand at those locations remained saturated. The location L4 laid right above capillary saturation zone, thus soil there maintained a high degree of saturation during the tests, and all collected data were plotted near the saturation region. The water saturation at L5 and L8 became the constant value of $14-16 \%$ (Figure 5 and Figure 6).

\section{Numerical results}

According to the results in the previous research ${ }^{18}$, for convenience and to reduce the iteration step, the initial guess following van Genuchten parameters for medium sand and fine sand were: $P_{0 m}=1.4$ and $\lambda_{m}$ $=0.8 P_{0 f}=3.0$ and $\lambda_{f}=0.8$, respectively. Two unknown parameters in the van Genuchten model, $\mathrm{P}_{0}$ and $\lambda$, were determined by solving iteratively the general flow equation, updating the values of the parameters until the solution agrees with measured data. After 8 iterations, inversion results converged to $P_{0 m}=$ 1.61 and $\lambda_{m}=0.92$ for medium sand and fine sand, respectively.

Figure 7 show the evolution of discharge rate with time from the experimental observations and reproduced numerical results. The predicted value of discharge rate calculated using assessed hydraulic parameters produced a good agreement with experimental observations, although there exist differences right after beginning of testing (Figure 7).

The comparison between predicted data and measured data of pore water pressure shows good agreement $(\mathrm{RMSE}=0.006$, Figure 8$)$. This Figure indicates that at the location of L2 and L4, the predicted values of pore water pressure were higher than the measured values of pore water pressure only after around $10-$ $20 \mathrm{~min}$. However, at location of L5 and L8, the predicted values of pore water pressure taken long time (after $40-50 \mathrm{~h}$ ) to be higher measured values of pore water pressure.

The Figure 9 a shows how good comparison between predicted data and measured data of soil saturation. The collective values with time at the same location of both soil saturation and pore-water pressure can be compiled into the SWCC (Figure 9). The difference of pore system between the lower part and the upper part in soil column and dramatic changes of pore water pressure at bottom of soil column cause the hysteresis at L2, L4 and L5 (Figure 9). However, because the upper part has higher hydraulic conductivity than the lower part, the hysteresis at L2, L4 and L5 is relative small. The water front rapidly dropped down at the beginning of testing, the lack of soil saturation data at some locations near the soil surface therefore can be happen, so using the multi-step outflow experiment can help cover the full range of the SWCC plot. The finite element and inverse analysis contain the sums of squared deviations between measured and simulated hydraulic properties. The comparison was conducted by computing the root mean square error (RMSE) from predicted and observed soil suction and soil saturation values using equation:

$$
R M S E=\sqrt{\frac{\sum_{i=1}^{N}\left(y_{i}^{m}-y_{i}^{p}\right)^{2}}{N}}
$$



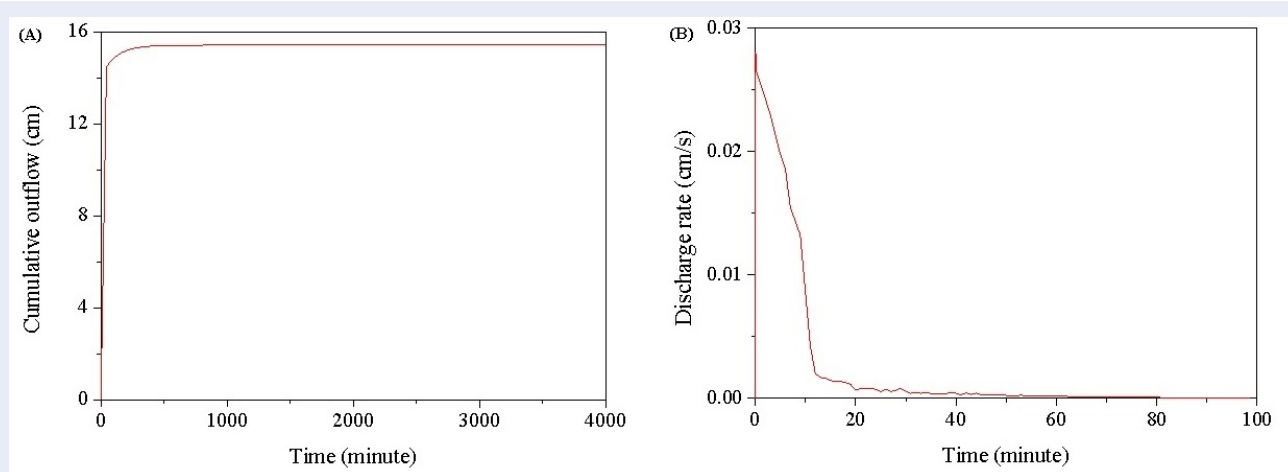

Figure 4: (A) Cumulative outflow with time; (B) Discharge rate with time.
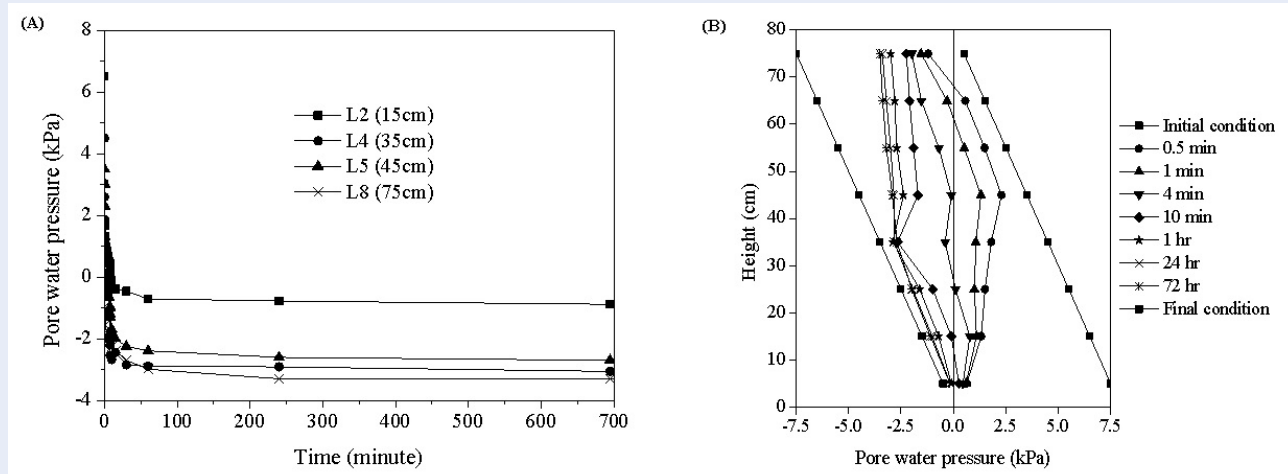

Figure 5: (A) Pore-water pressure with time at different heights in the sand column; (B) Pore-water pressure head profile in the sand column.
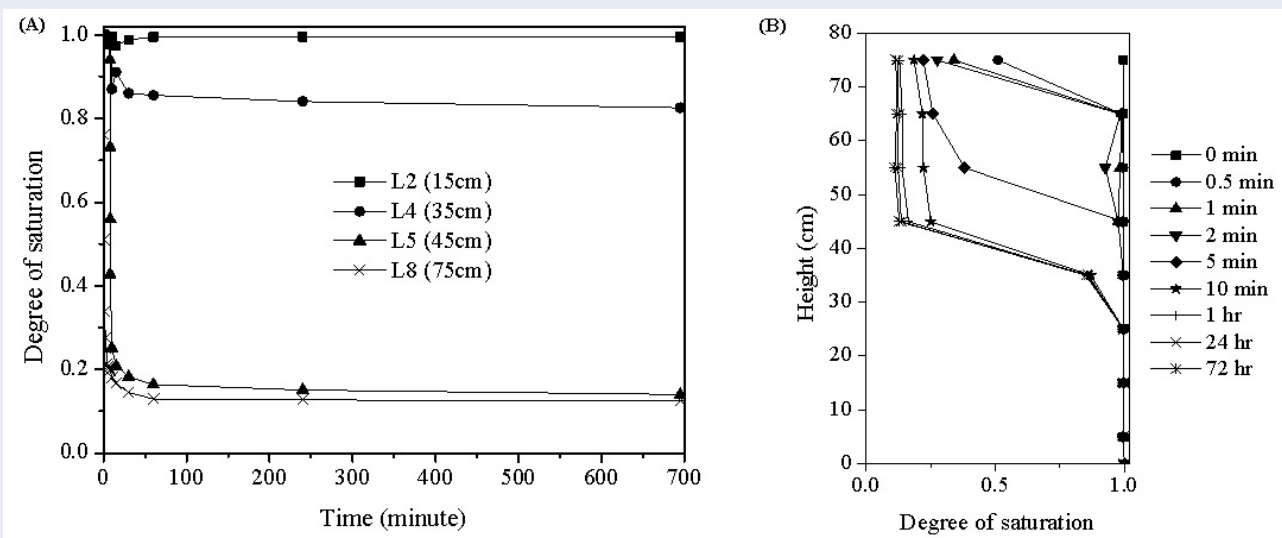

Figure 6: (A) Water saturation with time obtained at different heights in sand column; (B) Water saturation profile with height in sand column. 


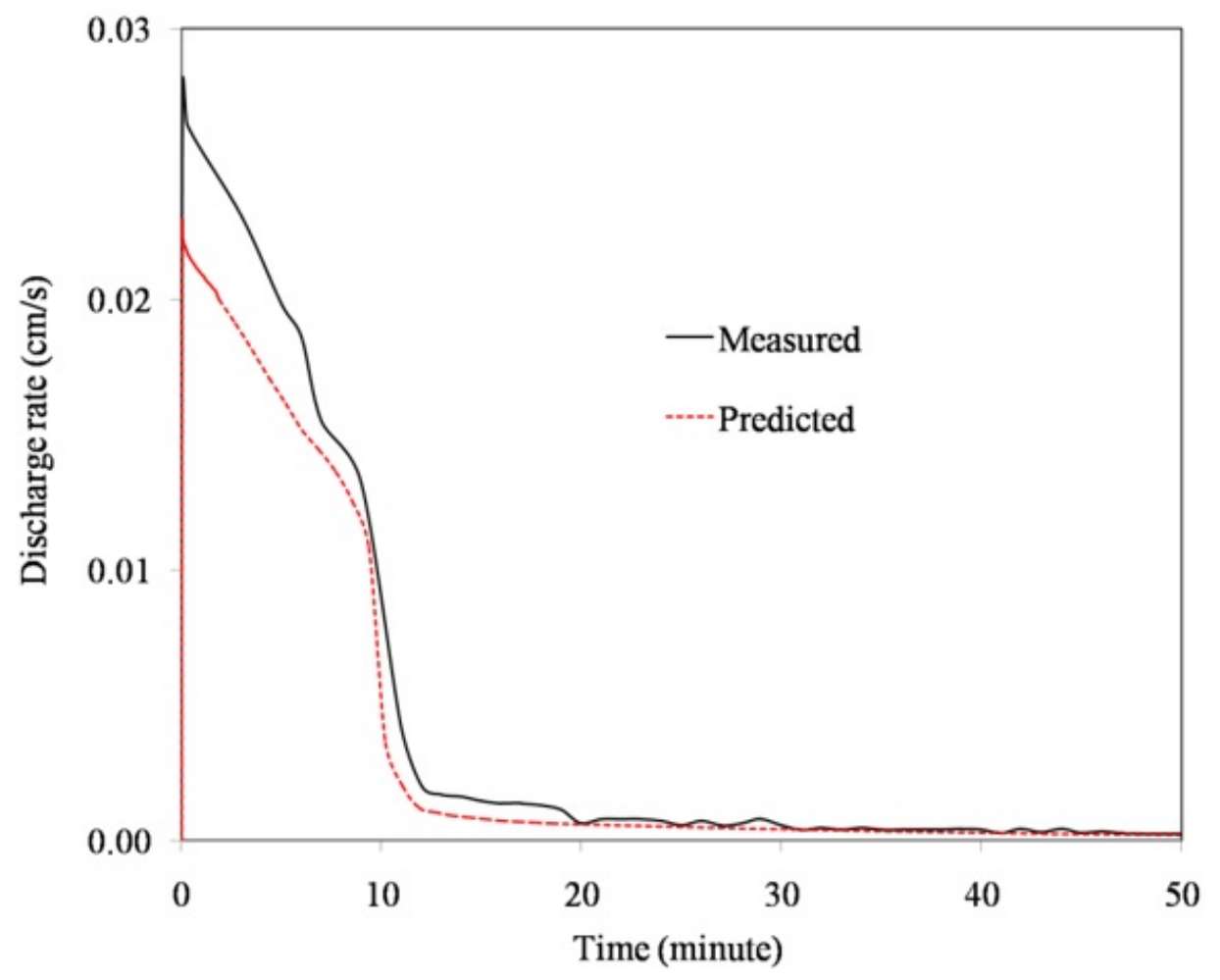

Figure 7: Comparison between predicted and measured outflow rate.

where $y_{i}^{m}$ represents experimental measurements, $y_{i}^{p}$ denotes predicted values using estimated soil properties such as pore-water pressure, degree of saturation and flow rate and $\mathrm{N}$ is total number of measurements. The Table 2 shows the accuracy of the fitting in comparison between the measured values and modeled values. The hysteresis phenomenon and narrow range of saturation contributed to the error in the evaluation of hydraulic properties, which can be proved with high values of RMSE at L4 and L5 (Table 2, Figure 8, Figure 9 a).

\section{CONCLUSIONS}

Since the inverse analysis was becoming a useful tool to determine the unsaturated hydraulic conductivity for homogeneous soil profile, many problems in Geoscience related to the unsaturated hydraulic parameters for heterogeneous soil profiles also have been considered because of the high similar condition of these problems with real site condition. Although many attempt have been made to determine the soil hydraulic parameters for heterogeneous soil profiles using inverse analysis, there is not yet satisfied affirmation in comparison with measured hydraulic prop- erties of unsaturated soils. For the present study, inverse analysis was applied to identify the unsaturated hydraulic function in the Richards' equation and van Genuchten model using outflow rate and suction, which were obtained from one-step outflow experiment for the layered sand column, at specific depths over time. Subsequently, the SWCC data given from combining measured soil suction and degree of saturation were compared with model predictions.

The weight factor and initial guessed values do not significantly affect the final identified parameters. However, with reasonable weight and initial guessed values, the calculation time will be faster and the final identified parameters will be more reliable.

With the same initial guessed values as the previous study ${ }^{18}$, the computed values for the layered sands converge faster than the homogeneous sand (8 iterative steps in this study vs 10 iterative steps in the previous study). This reason can be explained by the small ranges of water saturation and suction used as input data is small in the fine sand layer.

Application of the inverse analysis method to determine the unsaturated hydraulic properties for layered sand column has shown good results in comparison with the measurements. Therefore, the inversion 

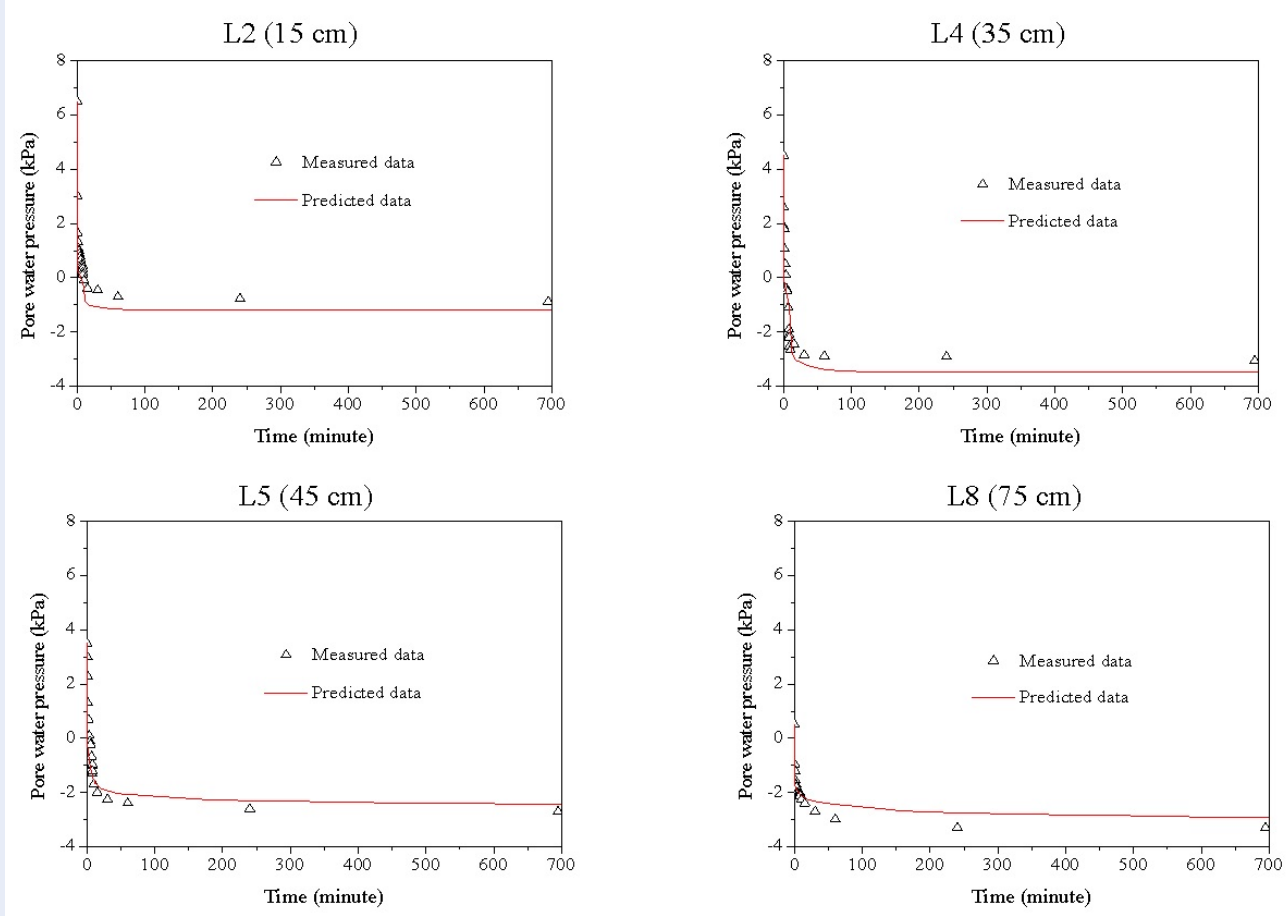

Figure 8: Comparison between predicted and measured pore water pressure at location of L2, L4, L5 and L8.

Table 2: RMSE from predicted and measured data in time domain.

\begin{tabular}{llccccccc}
\hline \multicolumn{3}{c}{ pore-water pressure (kPa) } \\
Location & L2 & L4 & L5 & L8 & L2 & L4 & L5 & L8 \\
RMSE & 0.263 & 0.688 & 0.436 & 0.335 & 0.007 & 0.061 & 0.042 & 0.036 \\
Average & 0.476 & & 0.283 & & 0.034 & & 0.039 & \\
\hline
\end{tabular}

analysis of a 1-D de-saturation column test could be a good indirect method to evaluate hydraulic properties of unsaturated layered sands.

Overall, in spite of a small difference in the comparison between measured and predicted data of inverse analysis applied for soil profiles which have heterogeneous hydraulic properties, a further investigation should be extended with consideration of the high hysteresis and capillary barrier conditions in determining the unsaturated hydraulic properties of soils at both laboratory and in situ scale.

\section{LIST OF ABBREVIATIONS}

1-D: One - Dimension

SWCC: Soil-Water Characteristic Curve

ERP: Electrical Resistivity Probes

WRC: Water Retention Curve

\section{COMPETING INTERESTS}

The authors guarantee that there is no conflict of interest in the publication of the article "Using inverse analysis to Estimate Hydraulic Properties for Unsaturated Layered Sand"

\section{CONTRIBUTION OF THE AUTHORS}

To Viet Nam experiments, runs simulations, analyzes results and writes the manuscript

Nguyen Viet Ky: comments the results and the manuscript

\section{ACKNOWLEDGEMENTS}

This research was supported by the Research Fund of University of Ulsan, Korea.

\section{REFERENCES}

1. Hopmans JW, Simunek J, Romano N, Durner W. Simultaneous determination of water transmission and retention properties. Inverse Methods. IN: Methods of Soil Analysis. Part 4. 
(A)

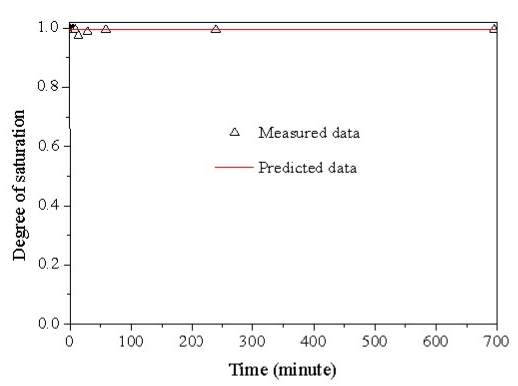

L5 (45 cm)
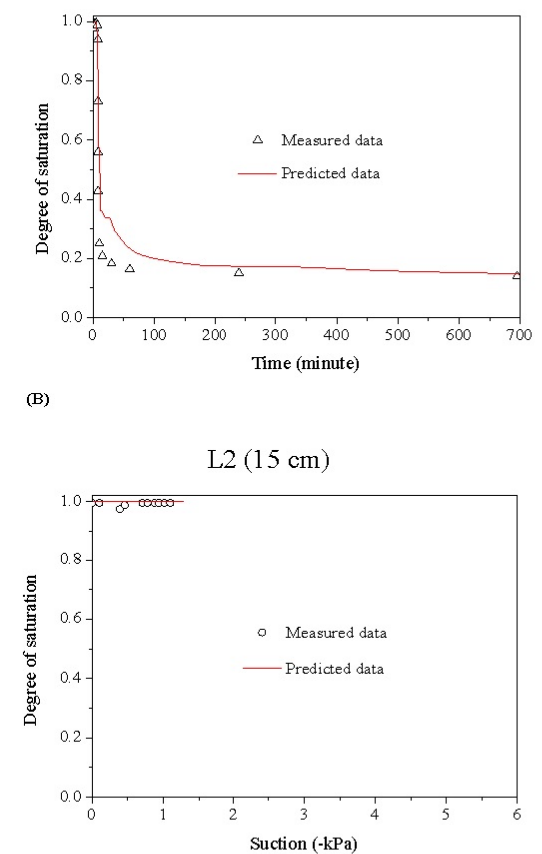

$\mathrm{L} 5(45 \mathrm{~cm})$

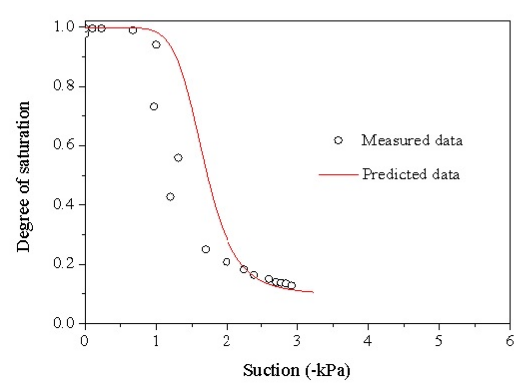

$\mathrm{L} 4(35 \mathrm{~cm})$

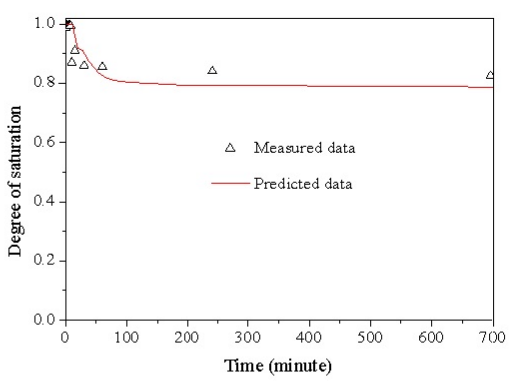

L8 $(75 \mathrm{~cm})$

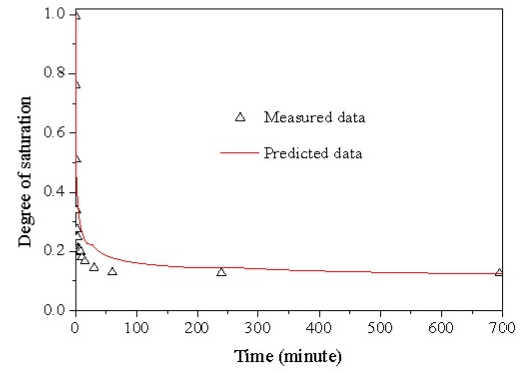

L4 $(35 \mathrm{~cm})$

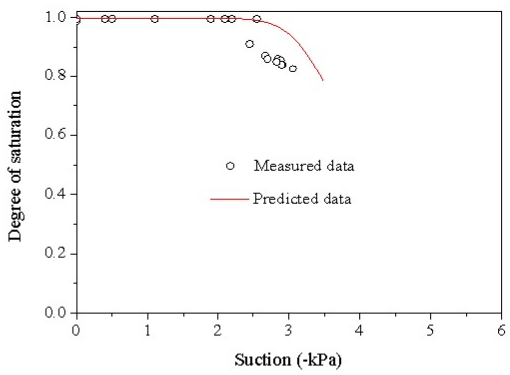

L8 $(75 \mathrm{~cm})$

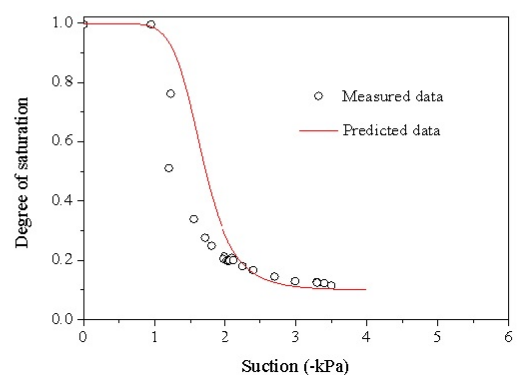

Figure 9: Comparison between predicted and measured hydraulic properties at location of 2, 4, 5 and 8: (a) change in degree of saturation; (b) compiled SWCC. 
Physical Methods. (J.H. Dane and G.C. Topp, Eds.). Soil Science Society of America Book Series. 2002;(5):963-1008. Available from: https://www.researchgate.net/publication/260185231.

2. Yeh TC. A review of scale problem and applications of stochastic methods to determine groundwater travel time and path. Dep Of Hydrol And Water Resources, University of Arizona, Tucson. 1989a;p. 199. Available from: https://repository.arizona.edu/bitstream/handle/10150/ 614214/HWR-1989-010_w.pdf.

3. Yeh TCJ, Harvey DJ. Effective unsaturated hydraulic conductivity of layered sands. Water Resources Research. 1990;26(6):1271-1279. Available from: https://doi.org/10. 1029/WR026i006p01271.

4. Saxton KE, Rawls WJ, Romberger JS, Papendick RI. Estimating generalized soil water characteristics from texture. Trans ASAE. 1986;50:1031-1035. Available from: https://doi.org/10. 2136/sssaj1986.03615995005000040039x.

5. Raats PAC. On the roles of characteristic lengths and times in soil physical processes. 14th International Congress of Soil Science. 1990;1. Available from: https://www.researchgate.net/ publication/316234032.

6. Durner W. Predicting the unsaturated hydraulic conductivity using multi-porosity water retention curves. In MTh van Genuchten et al (ed) Proceedings of the International Workshop on Indirect Method for Estimation the Hydraulic Properties of Unsaturated Soils University of California, Riverside. 1992;p. 185 -202. Available from: http://www.soil.tu-bs.de/ download/downloads/pubs/1992.Durner.Bimod.pdf.

7. Dam JC, Stricker JNM, Droogers P. Inverse Method for Determining Soil Hydraulic Functions from One-Step Outflow Experiments. Soil Sci Soc Am J. 1992;56:10421050. Available from: https://doi.org/10.2136/sssaj1992. 03615995005600040007x.

8. Simunek J, Genuchten MT. Estimating unsaturated soil hydraulic properties from tension disc infiltrometer data by numerical inversion. Water Resour Res. 1996;32:2683-2696. Available from: https://doi.org/10.1029/96WR01525.

9. Lehmann F, Ackerer P. Determining Soil Hydraulic Properties by Inverse Method in One-Dimensional Unsaturated Flow. Journal of environmental quality. 1997;26(1):76 -81. Available from: https://doi.org/10.2134/jeq1997. 00472425002600010012x.

10. Abbaspour KC, Genuchten MT, Schulin R, Schlappi E. A sequential uncertainty domain inverse procedure for estimating subsurface flow and transport parameters. Water Resour Res. 1997;33:1879-1892. Available from: https://doi.org/10.1029/ 97WR01230.

11. Szymkiewicz A, Helmig R. Comparison of conductivity averaging methods for one-dimensional unsaturated flow in layered soils. Advances in Water Resources. 2011;34(8):10121025. Available from: https://doi.org/10.1016/j.advwatres. 2011.05.011.

12. Singh MP, Chauhan HS, Ram S. Unsteady state drainage in a vertically heterogeneous soil. Agricultural Water Manage- ment. 1996;31(3):285-293. Available from: https://doi.org/10. 1016/0378-3774(96)01239-5.

13. Srinilta. Steady flow of water through a two-layered soil. Water Resour Res. 1969;(5). Available from: https://doi.org/10.1029/ WR005i005p01053.

14. Sisson JB. Drainage from layered field soils: Fixed gradient models. Water Resour Res. 1987;23:2071-2075. Available from: https://doi.org/10.1029/WR023i011p02071.

15. Romano N, Brunone B, Santini A. Numerical analysis of onedimensional unsaturated flow in layered soils. Adv Water Resour. 1996;21(4):315 -324. Available from: https://doi.org/10. 1016/S0309-1708(96)00059-0.

16. Kechavarzi C, Soga K, Illangasekare T, Nikolopoulos P. Laboratory study of immiscible contaminant flow in unsaturated layered sands. Vadose Zone Journal. 2008;7(1):1-9. Available from: https://doi.org/10.2136/vzi2006.0177.

17. Dam JC, Feddes RA. Modelling of water flow and solute transport for irrigation and drainage. Sustainability of Irrigated Agriculture. 1996;p. 211-231. Available from: https://doi.org/ 10.1007/978-94-015-8700-6_13.

18. Nam TV, Min TK, Shin HS. Using inverse analysis to estimate hydraulic properties of unsaturated sand from one-dimension outflow experiments. Engineering Geology. 2013;164:163171. Available from: https://doi.org/10.1016/j.enggeo.2013.07. 005.

19. Sharma RS, Mohamed MHA. An experimental investigation of LNAPL migration in unsaturated/saturated sand. Engineering Geology. 2003;70:305-313. Available from: https://doi.org/10. 1016/S0013-7952(03)00098-X.

20. Archie GE. The electrical resistivity log as an aid in determining some reservoir characteristics. Petroleum Transactions of AIME. 1942;146:54-62. Available from: https://doi.org/10. 2118/942054-G.

21. Lewis J. Optimizing the experimental design of unsaturated soil columns. 19th World Congress of Soil Science, Soil Solutions for a Changing World. 2010;Available from: https://www. iuss.org/19th\%20WCSS/Symposium/pdf/0168.pdf.

22. Kechavarzi C, Soga K. Determination of Water Saturation Using Miniature Resistivity Probes During Intermediate Scale and Centrifuge Multiphase Flow Laboratory Experiments. Geotechnical testing journal, GTJODJ. 2002;25(1):95103. Available from: https://doi.org/10.1520/GTJ11084J.

23. Genuchten MT. A Closed-Form Equation for Predicting the Hydraulic Conductivity of Unsaturated Soils. Soil Science Society Am J. 1980;44:892-898. Available from: https://doi.org/ 10.2136/sssaj1980.03615995004400050002x.

24. Santamarina JC, Fratta D. Discrete Signals and Inverse Problems. Wiley, New York. 2005;Available from: https://www.bookdepository.com/Discrete-Signals-InverseProblems-J-C-Santamarina/9780470021873.

25. Shin H, Santamarina JC. Desiccation cracks insaturated finegrained soils: particle-level phenomena and effective-stress analysis. Géotechnique. 2011;61(11):961-972. Available from: https://doi.org/10.1680/geot.8.P.012. 


\title{
Sử dụng phân tích ngược để đánh giá đặc tính thủy lực của cát phân lớp chưa bão hòa
}

\author{
Tô Viết Nam*, Nguyễn Việt Kỳ
}

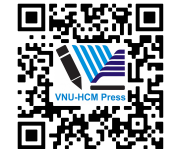

Use your smartphone to scan this QR code and download this article

\section{TÓM TẮT}

Nhằm đánh giá tốt hơn khả năng ứng dụng của phương pháp phân tích ngược trong tính toán và đánh giá các đặc tính thủy lực của đất không bão hòa trong điều kiện gần thực tế hơn, một thí nghiệm thoát nước cho cát phân lớp đã được áp dụng trong điều kiện tháo khồ với mục đích có được các thông tin về lực hút, độ bão hòa và lưu lượng thoát nước theo thời gian. Trong nghiên cứu này, cát mịn và cát trung bình được đưa vào sử dụng với độ dày là $40 \mathrm{~cm}$ cho mỗi lớp cát. Các hạt cát được rót vào trong cột plexiglas trong suốt chứa nước $(H=80 \mathrm{~cm}, \mathrm{D}=28 \mathrm{~cm}$, chiều dày thành $=1 \mathrm{~cm}$ ) nhằm chuẩn bị được mẫu bão hòa hoàn toàn. Để đảm bảo tính đồng nhất trong mỗi lớp cát, độ chặt của hai lớp cát phải được kiểm soát trong suốt quá trình tạo mẫu thí nghiệm. Đối với nghiên cứu số, Sử dụng phương pháp phân tích ngược và tính trực tiếp để xác định đặc tính thủy lực của cát chưa bão hòa. Những tham số thủy lực chưa bão hòa trong mô hình van Genuchten được tính toán bằng cách sử dụng lực hút đo được tại mỗi độ cao cách nhau $10 \mathrm{~cm}$ và lưu lượng nước thoát ra tại đáy của cột cát phẩn lớp. Nhằm giảm số lượng dữ liệu phân tích và tính toán nhưng vẫn giữ đủ thông tin điển hình cho thí nghiệm, bốn bộ dữ liệu về lực hút và độ bão hòa của đất tại bốn vị trí (L2, L4, L5 và L8) trong tổng số tám vị trí đã được chọn ra để xây dựng đường cong đặc trưng nước đất. So sánh giữa các đặc tính thủy lực từ mô phỏng và từ thí nghiệm cho kết quả tốt trong trường hợp cát mịn nằm phía dưới cát trung bình. Kết quả cũng cho thấy rằng bên cạnh cát đổng nhất, phương pháp phân tích ngược dựa trên thí nghiệm thoát nước một chiều hứa hẹn là một phương pháp hữu ích trong việc xác định các đặc tính thủy lực cho cát phân lớp chưa bão hòa.

Từ khoá: tính thấm không bão hòa, bài toán ngược, thí nghiệm trụ một chiều, phương pháp phần tử hữu hạn, đất không đông nhất
Bộ môn Đia Kr̃ Thuật, Đai học Bách Khoa TP.HCM

Liên hệ

Tô Viết Nam, Bộ môn Địa Kỹ Thuật, Đại học Bách Khoa TP.HCM

Email: tovietnam@hcmut.edu.vn

Lịch sử

- Ngày nhận: 25-3-2020

- Ngày chấp nhận: 04-11-2020

- Ngày đăng: 13-11-2020

DOI :10.32508/stdjsee.v4i2.527

\section{Check for updates}

\section{Bản quyền}

๑ Đ ĐHQG Tp.HCM. Đây là bài báo công bố mở được phát hành theo các điều khoản của the Creative Commons Attribution 4.0 International license.

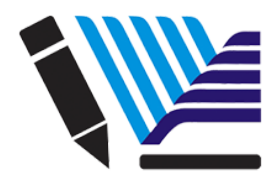

VNU-HCM Press
Trích dẫn bài báo này: Nam TV, Kỳ N V. Sử dụng phân tích ngược để đánh giá đặc tính thủy lực của cát phân lớp chưa bão hòa. Sci. Tech. Dev. J. - Sci. Earth Environ.; 4(2):206-217. 